\section{Species-Pairs among Insects}

AtTention has recently been directed to the water beetles Deronectes depressus $\mathrm{F}$. and $D$. elegans Panz. by $\mathrm{F}$. Balfour-Browne in an interesting contribution to the Scottish Naturalist (Nov.-Dec. 1930, pp. 172188). In a previous study (Ann. Mag. Nat. Hist., Ser. 9, vol. 3, pp. 293-308; 1919) he showed that these two species could be separated by a number of characters-size, shape, colour, tarsal claws, width of ædeagus - but that intermediates could be found which formed an unbroken series connecting the two by insensible gradations. His recent paper discusses the distribution, which is of great interest. In southern England, D. elegans only occurs ; in northern England and southern Scotland, both species are found, with all grades of intermediates; in northern Scotland and throughout Ireland, only $D$. depressus and intermediates approximating to the $D$. depressus type occur.

In 1927 Georg Ochs (Koleopt. Rundschau, Bd. 13, pp. 34-36) directed attention to the whirligig beetles known as Gyrinus natator L., and showed that two forms, separable by size, colour, shape, punctuation, and slight differences in the rdeagus, were confused under this name. The true $G$. natator $\mathrm{L}$. is found in the north-eastern palæarctic region, while the other form, G. substriatus Stephens, occurs in south-west Europe. At the extremes of their range both forms occur without admixture, while in northern Europe both can be found side by side. The common British form is G. substriatus, and D. Sharp, who examined very large numbers, appears to have met with no other. I have recently found a dark form occurring in Cambridgeshire and Scotland, which I described as G. natator var. fowleri (Ent. Mon. Mag., vol. 66, p. $74 ; 1930$ ). Since then, through the kindness of F. H. Day and $H$. Britten, I have examined specimens of the true $G$. natator $\mathrm{L}$. from Cumberland. My specimens of $G$. natator var. fowleri form an almost perfect series connecting $G$. natator $\mathbf{L}$. and $G$. substriatus Steph.

It therefore appears that we possess in $G$. natatorsubstriatus a species-pair almost exactly paralleling the $D$. depressus-elegans pair so beautifully worked out by Balfour-Browne. This seems unlikely to be mere coincidence, particularly as both the northern species are characterised by melanism and pure races of the southern species occur in southern England. It may be that other similar pairs exist in other groups. No doubt a proper study of such species will go far towards a solution of some aspects of that difficult matter the 'species problem', and throw new light on the process of evolution, here apparently in actual progress. I would therefore be glad to have further information and also material of Gyrinus, preferably in alcohol, from different localities, particularly Scottish, Irish, and Continental. JOSEPH OMER-COOPER.

Armstrong College,

Newcastle-upon-Tyne, Jan. 22.

\section{Gurling}

I HAVE read with considerable interest the letter on curling by W. H. Macaulay and Brig.-General G. E. Smith in NaTURE of Jan. 10, in which they attribute the final twist of the curling-stone to regelation. But surely the time has come when regelation in this connexion should be relegated to the place of a laboravery myth, and might almost disappear from elementare text-books. In 1921 the late Sir George Beilby produced his famous book on "Aggregation and Flow of Bolids" (Macmillan and Co., Ltd.) and showed that these familiar ice problems can only be explained on the theory of surface and mass flow.
It is doubtful whether a really heavy man, even if he were standing on one skate only, could exert sufficient pressure to raise the temperature of the ice to anything like the amount required by the theory of regelation, while a curling-stone weighs only a few pounds and presents, relative to a man on one skate, a very large surface to the ice.

In curling, one is dealing with a large number of factors, but it is more or less possible to single out three which are of primary importance.

The first consists of the direction of mass-flow of the ice. On a really cold morning, and in the absence of surf and on a carefully flooded rink, this should be more or less constant. Anything like a rise in tem. perature caused by bright sunlight will upset the conditions considerably, and hence the interesting but somewhat disconcerting variability of the ice as the sun rises over the hills and throws its welcome rays on those who are curling, about eleven o'clock in the morning during the winter sports season in Switzerland.

In the actual curling there are two main forces acting on the stone in addition to gravity. 'These are, of course, the initial forward motion of the stone and the twist or handle. Both of these are inducing surface-flow on the ice, and the actual direction of the stone is the resultant of these two forces, one or both of which may be opposed or reinforced by the direction of mass-flow of the ice: and hence the very intricate nature of the problem. It is easy to see that if the direction of mass-flow of the ice is the opposite to that of the initial direction of the stone, as the stone slows down a considerable amount of rotation may occur, and the stone may even remain stationary but rotating.

Beilby showed that the normal surface of the ice, or that due to mass-flow, is entirely different from the vitreous surface due to surface-flow; the ice composing the surface of the one being stable in the absence of friction, while the ice composing the vitreous film is only stable at temperatures far below the normal melting-point of ice. The conditions on the typical curling-rink in Switzerland are such that the transitions of surface-flow to mass-flow are very rapid and, in some cases, almost instantaneous.

That the problem is essentially one of the resultant of mass-flow and surface-flow is strongly borne out by the effect of sweeping. Anyone who has been on the curling-rink must have noticed the almost astounding effect that can be produced by good sweeping. The real effect of an expert sweeper is to induce a strong surface-flow and hence a vitreous film immediately in front of the stone: hence the velocity of the stone is maintained and it does not curl.

Marlborough College,

\section{A. G. Lowndes.} Wilts.

Biology in Education and Human Life.

IN my Henry Sidgwick Memorial Lecture (NATURE, Jan. 3, 1931) I protested that "those should be re. garded as lacking education who are altogether ignorant of the nature of living things" (p. 21). Mr. A. D. Ritchie has directed my attention to a sentence of Robert Boyle's, who about two and a half centuries ago, in much more beautiful words than mine, urged similarly that it is " highly dishonourable for a reasonable soul to live in so divinely built a mansion as the body she resides in altogether unacquainted with the exquisite structure of it". A. V. HILr.

University College,

Gower Street, London, W.C.1, Jan. 23. 